\begin{tabular}{|c|c|}
\hline Title & $\begin{array}{l}\text { Diet of the mesopelagic fish Notoscopelus japonicus (Family: Myctophidae) associated with the continental slope off } \\
\text { the Pacific coast of Honshu, Japan }\end{array}$ \\
\hline Author(s) & Uchikawa, Kazuhisa; Y amamura, Orio; Kitagawa, Daiji; Sakurai, Y asunori \\
\hline Citation & $\begin{array}{l}\text { Fisheries Science, 68(5), 1034.1040 } \\
\text { https://doi.org/10.1046j.1444.2906.2002.00529.x }\end{array}$ \\
\hline Issue Date & $2002-10$ \\
\hline Doc URL & http:/hdl. handle.net/2115/35584 \\
\hline Rights & ○ 2002 公益社団法人日本水産学会; @ 2002 T he Japanese Society of Fisheries Science \\
\hline Type & article \\
\hline File Information & 2002-68_p1034 1040.pdf \\
\hline
\end{tabular}

Instructions for use 


\title{
Diet of the mesopelagic fish Notoscopelus japonicus (Family: Myctophidae) associated with the continental slope off the Pacific coast of Honshu, Japan
}

\author{
KaZUhisa UCHIKAWA, ${ }^{1{ }^{* \dagger}}$ Orio YAMAMURA, ${ }^{2}$ DAIJI KITAGAWA ${ }^{3}$ AND YasunORI SAKURAI ${ }^{1}$ \\ ${ }^{1}$ Graduate School of Fisheries Sciences, Hokkaido University, Hakodate, Hokkaido 041-8611, \\ ${ }^{2}$ Hokkaido National Fisheries Research Institute, Kushiro, Hokkaido 085-0802 and \\ ${ }^{3}$ Tohoku National Fisheries Research Institute, Hachinohe, Aomori 031-0841, Japan
}

\begin{abstract}
The diet of Notoscopelus japonicus, one of the dominant mesopelagic fishes in the transitional waters of the western North Pacific, was examined in 106 specimens collected over the continental slope off the Pacific coast of northern Japan during April and October 1996. The prey comprised mainly crustaceans, such as copepods, ostracods, euphausiids and amphipods. Euphausia pacifica was the dominant prey, representing $83.1 \%$ by number and $72.4 \%$ by wet weight of the total diet. Between April and October, there was no shift in prey species consumed, but prey size decreased significantly and prey number per fish stomach increased in October. These results indicate that, in October, $N$. japonicus consumed larger numbers of smaller E. pacifica, rather than shifting to other prey taxa. The pronounced importance of E. pacifica in the diet was ascribed to its co-occurrence with $N$. japonicus at night in the surface layer and during the daytime in the nearbottom layer.
\end{abstract}

KEY WORDS: diet, Euphausia pacifica, euphausiids, mesopelagic fish, myctophids, Notoscopelus japonicus, upper continental slope.

\section{INTRODUCTION}

Myctophids are a dominant component of the pelagic ecosystems, ${ }^{1}$ where they generally prey on crustacean zooplankton and are consumed by marine birds, ${ }^{2}$ marine mammals ${ }^{3}$ and fish. ${ }^{4}$ They also form dense aggregations near continental slopes, ${ }^{5-8}$ where they may also play an important role in the near-shore ecosystem.

Notoscopelus japonicus is one of the most dominant myctophids in the transitional western North Pacific. ${ }^{9-11}$ Off the Pacific coast of northern Japan (Tohoku region), especially near the continental slope, $N$. japonicus is heavily consumed by marine mammals, such as the northern fur seal Callorhinus ursinus ${ }^{12,13}$ and Dall's porpoise Phocoenoides dalli. ${ }^{14,15}$ Furthermore, dominant demersal fishes, such as the Pacific cod Gadus macrocephalus and walleye pollock Theragra chalcogramma, consume

\footnotetext{
*Corresponding author: Tel: 81-543-36-6057. Fax: 81-543-359642. Email: stomyct@fra.affrc.go.jp

${ }^{\dagger}$ Present address: National Research Institute of Far Seas Fisheries, Shimizu, Shizuoka 424-8633, Japan.

Received 3 September 2001. Accepted 11 March 2001.
}

$N$. japonicus in this region. ${ }^{16}$ Thus, $N$. japonicus plays an important role in transferring organic material from lower trophic levels to higher trophic levels in both the pelagic and the near-bottom layers over the continental slope. In spite of the ecologic importance of $N$. japonicus, no information is available on its feeding habits. The present study reports the diet of $N$. japonicus associated with the continental slope in the Tohoku region.

\section{MATERIALS AND METHODS}

Specimens were collected during two demersal fish surveys conducted by the Tohoku National Fisheries Research Institute in April 1996 (R/V TanshuMaru) and October 1996 (R/V Wakataka-Maru). During the cruises, a bottom trawl with a mouth opening of $3.3 \times 18.2 \mathrm{~m}$ was towed at an average ship speed of 3 knots $(5.7 \mathrm{~km} / \mathrm{h})$. The net had an $8 \mathrm{~mm}$ mesh codend lining and was towed for $30 \mathrm{~min}$ at fishing depth at each sampling station. The location of stations and detailed sampling data are shown in Fig. 1 and Table 1. A total of 11 tows was made during the day and one was made at 


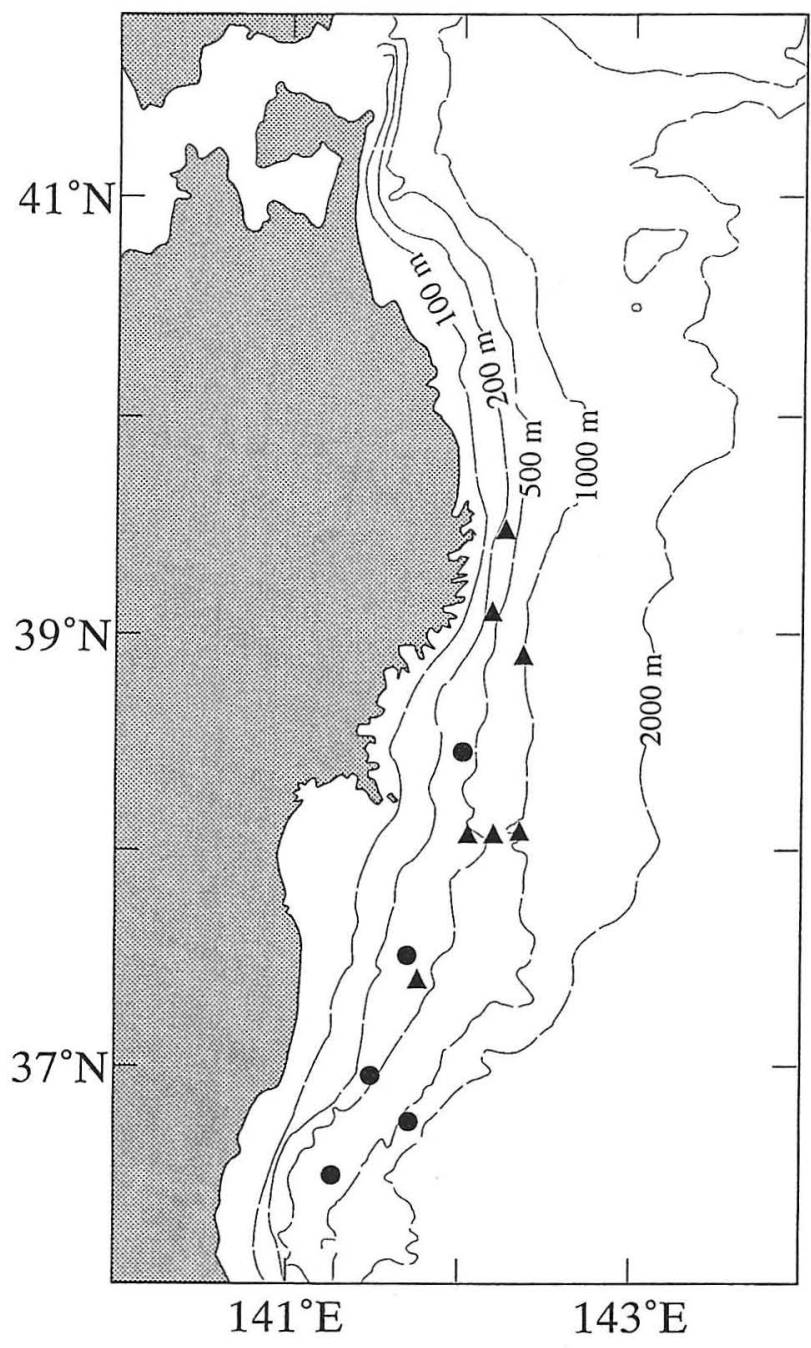

Fig. 1 Locations of bottom trawl stations. (O) R/V Tanshu-Maru cruise during April 1996; (A) R/V Wakataka-Maru cruise during October 1996. dusk (Table 1). Oceanographic observations were made in the area delineated by the latitudes $36^{\circ} 30^{\prime} \mathrm{N}$ and $38^{\circ} 30^{\prime} \mathrm{N}$ in April and $36^{\circ} 30^{\prime} \mathrm{N}$ and $41^{\circ} 30^{\prime} \mathrm{N}$ in October and the 150 and $1800 \mathrm{~m}$ isobaths. Water temperature was measured from the sea surface to just above the sea floor using an expendable bathythermograph (XBT) along five (April; 29 stations) and 10 (October; 61 stations) latitudinal transects.

Fish samples were fixed in a $10 \%$ buffered formaldehyde seawater solution at sea and then transferred to $50 \%$ isopropyl alcohol in the laboratory. Each fish was measured to the nearest $0.1 \mathrm{~mm}$ standard length (SL), weighed to the nearest $0.1 \mathrm{~g}$ wet body weight and the stomach was then dissected out. Prey was identified to the lowest taxon possible, counted and weighed to the nearest 0.1 mg. Prey found in the mouth cavity and esophagus of fish was excluded from the analysis because it could have been ingested in the net. Some individuals had digested prey items in their mouth cavities, which indicated an occurrence of regurgitation, but no empty stomachs resulting from regurgitation or everted stomachs were observed, suggesting that regurgitation was negligible for this study. Fish scales (probably from myctophids) and all but one ophiuroid arm found in the stomachs were excluded from the diet analysis, because they were considered to be ingested in the net. The one ophiuroid arm included in the analysis apparently resulted from natural feeding activity because it was surrounded by digested euphausiids. Two copepod species, namely Neocalanus plumchrus and $N$. flemingeri, and two amphipod species, namely Themisto japonica and T. pacifica, were treated as $N$. plumchrus/flemingeri and $T$. japonica/pacifica, respectively, due to the difficulty

Table 1 Sampling data of bottom trawls conducted off the Pacific coast of Honshu, Japan

\begin{tabular}{|c|c|c|c|c|c|c|c|}
\hline \multirow[b]{2}{*}{ Data } & & \multirow[b]{2}{*}{ Vessel } & \multicolumn{2}{|c|}{ Sampling locality } & \multirow{2}{*}{$\begin{array}{l}\text { Trawling } \\
\text { mid-time (h) }\end{array}$} & \multirow{2}{*}{$\begin{array}{l}\text { Sampling } \\
\text { depth (m) }\end{array}$} & \multirow{2}{*}{$\begin{array}{l}\text { Specimens } \\
\text { examined }\end{array}$} \\
\hline & & & Latitude (N) & Longitude (E) & & & \\
\hline \multirow[t]{5}{*}{ April } & 12 & TM & $38^{\circ} 28^{\prime}$ & $142^{\circ} 02^{\prime}$ & $07: 11$ & $408-415$ & 73 \\
\hline & 17 & TM & $37^{\circ} 31^{\prime}$ & $141^{\circ} 29^{\prime}$ & 07:31 & $410-415$ & 3 \\
\hline & 15 & TM & $36^{\circ} 58^{\prime}$ & $141^{\circ} 34^{\prime}$ & $13: 44$ & $399-401$ & 1 \\
\hline & 19 & TM & $36^{\circ} 30^{\prime}$ & $141^{\circ} 16^{\prime}$ & 09:54 & $806-813$ & 3 \\
\hline & 19 & TM & $36^{\circ} 45^{\prime}$ & $141^{\circ} 43^{\prime}$ & $15: 12$ & 1408 & 1 \\
\hline \multirow[t]{7}{*}{ October } & 7 & WM & $39^{\circ} 29^{\prime}$ & $142^{\circ} 16^{\prime}$ & $06: 37$ & $373-383$ & 17 \\
\hline & 8 & WM & $39^{\circ} 07^{\prime}$ & $142^{\circ} 10^{\prime}$ & $06: 49$ & 395 & 1 \\
\hline & 8 & WM & $38^{\circ} 55^{\prime}$ & $142^{\circ} 22^{\prime}$ & $15: 14$ & $940-946$ & 1 \\
\hline & 16 & WM & $38^{\circ} 05^{\prime}$ & $142^{\circ} 03^{\prime}$ & $12: 14$ & $406-417$ & 1 \\
\hline & 16 & WM & $38^{\circ} 04^{\prime}$ & $142^{\circ} 12^{\prime}$ & *17:26 & $796-801$ & 1 \\
\hline & 17 & WM & $38^{\circ} 06^{\prime}$ & $142^{\circ} 21^{\prime}$ & 07:07 & $998-1000$ & 1 \\
\hline & 18 & WM & $37^{\circ} 25^{\prime}$ & $141^{\circ} 48^{\prime}$ & $11: 05$ & $400-412$ & 3 \\
\hline
\end{tabular}

Total

106

TM: R/V Tanshu-Maru; WM: R/V Wakataka-Maru.

*Trawling was made after sunset (sunrise: $05.00 \mathrm{~h}$ (April), $05.30 \mathrm{~h}$ (October); sunset: $18.10 \mathrm{~h}$ (April), $17.00 \mathrm{~h}$ (October)). 
in identification of partly digested materials. A stomach contents index $(S C I)$ was calculated as follows:

$$
\begin{aligned}
S C I(\%)= & \text { (wet weight total stomach contents } / \\
& \text { wet body weight }) \times 100
\end{aligned}
$$

The diet of $N$. japonicus was expressed as the percentage of each prey type of the total number of prey identified $(\mathrm{Cn})$, the percentage of each prey type of the total wet weight of prey identified (WW) and the percentage of stomachs in which each prey type was found $(F)$. Based on these indices, we calculated an index of relative importance (IRI): ${ }^{17}$

$$
I R I_{i}=F_{i} \times\left(C n_{i}+W W_{i}\right)
$$

for each prey category. The IRI for each category was then standardized to $\% I R I:{ }^{18}$

$$
\% I R I_{i}=100 \times I R I_{i} / \sum_{i}^{n} I R I_{i}
$$

where $n$ is the total number of prey categories considered at a given taxonomic level.

To assess the effects of season on diet composition, we compared prey composition ( $\mathrm{Cn} \%$ and $W W \%$ between April and October using the percent similarity index $(P S I):{ }^{19}$

$$
P S I=100-1 / 2 \sum_{i=1}^{n}\left|p_{x, i}-p_{y, i}\right|
$$

where $\mathrm{p}_{x . i}$ and $\mathrm{p}_{y, i}$ are the percentage of the $i$ th prey category in the diet for data of April and October, respectively. This coefficient ranges from $0 \%$ (no overlap) to $100 \%$ (complete overlap). There is no statistical method available to test the significance of PSI, so we considered diets to be similar when the PSI was $60 \%$, which is the criterion used in published reports. ${ }^{20-22}$ Because this index is sensitive to the taxonomic resolution of prey, we used the lowest taxonomic levels available (generally genus or species).

\section{RESULTS}

In the Tohoku region, the position of the Kuroshio front is defined to be where the temperature at $100 \mathrm{~m}$ depth is $14^{\circ} \mathrm{C}$ in April and $16^{\circ} \mathrm{C}$ in October and the position of the Oyashio front is defined to be where the temperature at $100 \mathrm{~m}$ depth is $5^{\circ} \mathrm{C}$ in April and $7{ }^{\circ} \mathrm{C}$ in October. ${ }^{23,24}$ The area between these fronts is regarded as transitional waters. In the present study area (Fig. 1), the average temperature at $100 \mathrm{~m}$ depth was lower during April (mean $\pm \mathrm{SD}=7.7 \pm 1.4^{\circ} \mathrm{C} ; 29 \mathrm{XBT}$ stations) than during October $\left(12.5 \pm 2.7^{\circ} \mathrm{C} ; 61 \mathrm{XBT}\right.$ stations). Neither front was observed during April in the study area. During October, the Kuroshio front occurred near $37^{\circ} \mathrm{N}$, indicating that all 12 sampling stations were located in transitional waters.

The stomach contents of 106 fish ranging from 108 to $144 \mathrm{~mm} \mathrm{SL}$ (mean \pm SD $=126.2 \pm 7.8$ $\mathrm{mm}$ ) were examined. Of these, only two individuals had empty stomachs. Median SL did not differ significantly between April $(125.8 \pm 8.1 \mathrm{~mm})$ and October $(127.5 \pm 6.6 \mathrm{~mm})(U=850, P=0.230$, Mann-Whitney $U$-test).

The diets in April and October were similar in composition in terms of prey number and weight ( $P S I=76$ and $64 \%$ for $C n$ and $W W$, respectively). Therefore, the data from both seasons were combined for later analysis.

The diet of $N$. japonicus included copepods, ostracods, amphipods, euphausiids, decapods and ophiuroids (Table 2), with crustaceans forming the largest portion of the diet $(C n=95.4 \% ; W W=99.8 \%$; $F=98.1 \%$ ). Euphausiids were the most dominant prey taxon ( $C n=85.3 \%$; $W W=97.2 \% ; F=98.1 \%$ ), Euphausia pacifica, which constituted 97.5 and $95.7 \%$ of the total number and wet weight of euphausiids, respectively (Table 2), was consumed by more than $82 \%$ of $N$. japonicus examined. Other euphausiid species, such as Thysanoessa longipes and Tessarabrachion oculatum were also ingested, but in low numbers. Copepods were the secondmost important prey taxon by number $(7.5 \%)$ and frequency of occurrence $(23.3 \%)$ and comprised more than 10 species, including Neocalanus cristatus, Candacia columbiae and Euchaeta rimana. However, the gravimetric contribution of copepods to the diet was low $(<2.1 \%)$. Sergestes similis, the only decapod crustacean in the diet, was eaten by $10 \%$ of the fish and was the second-most important prey by wet weight ( $W W=21.4 \%$ ), but was low in numerical importance $(\mathrm{Cn}=1.7 \%)$. Other prey taxa, such as conchoeciid ostracods, amphipods ( $T$. japonica/pacifica) and ophiuroids, accounted for $1.0 \%$ of each index. The \%IRI of euphausiids in the diet was $97.1 \%$, whereas the values for the five other prey taxa were all $\leq 1.5 \%$ (Table 2 ).

The $S C I$ ranged from 0 to 2.1, with an average of 0.6 in April, and from $<0.1$ to 1.6 with an average of 0.7 in October. Prey size ranged from 2.1 to $46.0 \mathrm{~mm}$ total length (TL). Prey items larger than 23 mm TL comprised only $S$. similis, whereas those smaller than $9 \mathrm{~mm}$ TL comprised copepods and ostracods. Over $70 \%$ of prey items ranging from 9 to $23 \mathrm{~mm}$ TL were euphausiids. All ingested E. pacifica were either juveniles or adults. Of E. pacifica ingested in April, $98 \%$ were $>13 \mathrm{~mm}$ TL, whereas $67 \%$ of those ingested in October were $>13 \mathrm{~mm}$ TL. Euphausia pacifica ingested in April were significantly larger than those ingested in October $(t=$ 
Table 2 Diet of Notoscopelus japonicus

\begin{tabular}{|c|c|c|c|c|}
\hline & $C n(\%)$ & $W W(\%)$ & $F(\%)$ & $\% I R I$ \\
\hline Crustacea (total) & 95.4 & 99.8 & 98.1 & \\
\hline $\begin{array}{l}\text { Copepoda (total) } \\
\text { Aetideopsis multiserrata } \\
\text { Neocalanus cristatus } \\
\text { Neocalanus plumchrus/flemingeri } \\
\text { Candacia columbiae } \\
\text { Euchaeta rimana } \\
\text { Euchaeta spp. } \\
\text { Paraeuchaeta elongata } \\
\text { Euchaetidae (unidentified) } \\
\text { Metridia okhotensis } \\
\text { M. pacifica } \\
\text { Metridia spp. } \\
\text { Pleuromanmma spp. } \\
\text { Scottocalanus securifrons } \\
\text { Calanoida (unidentified) }\end{array}$ & $\begin{array}{l}7.5 \\
0.1 \\
0.9 \\
0.1 \\
1.2 \\
1.3 \\
0.6 \\
0.1 \\
0.1 \\
0.1 \\
0.4 \\
0.3 \\
0.3 \\
0.1 \\
1.6\end{array}$ & $\begin{array}{r}2.1 \\
<0.1 \\
0.5 \\
<0.1 \\
0.2 \\
0.5 \\
0.4 \\
0.1 \\
<0.1 \\
<0.1 \\
<0.1 \\
<0.1 \\
<0.1 \\
<0.1 \\
0.3\end{array}$ & $\begin{array}{r}23.3 \\
1.0 \\
4.9 \\
1.0 \\
7.8 \\
3.9 \\
2.9 \\
1.0 \\
1.0 \\
1.0 \\
1.9 \\
1.9 \\
1.9 \\
1.0 \\
5.8\end{array}$ & 1.5 \\
\hline $\begin{array}{l}\text { Ostracoda } \\
\text { Conchoecia sp. }\end{array}$ & 0.1 & $<0.1$ & 1.0 & $<0.1$ \\
\hline Malacostraca (total) & 87.2 & 97.2 & 98.1 & \\
\hline $\begin{array}{l}\text { Amphipoda } \\
\text { Themisto japonica/pacifica }\end{array}$ & 0.1 & 0.1 & 1.0 & $<0.1$ \\
\hline $\begin{array}{l}\text { Euphausiacea (total) } \\
\text { Euphausia pacifica } \\
\text { Thysanoessa longipes } \\
\text { Thysanoessa spp. } \\
\text { Tessarabrachion oculatum } \\
\text { Euphausiidae (unidentified) } \\
\text { Euphausiacea (unidentified) }\end{array}$ & $\begin{array}{r}85.3 \\
8.1 \\
0.1 \\
0.1 \\
0.4 \\
0.1 \\
1.3\end{array}$ & $\begin{array}{r}75.7 \\
72.4 \\
0.5 \\
0.4 \\
0.9 \\
0.1 \\
1.3\end{array}$ & $\begin{array}{r}92.2 \\
82.5 \\
1.0 \\
1.0 \\
2.9 \\
1.0 \\
6.8\end{array}$ & 97.1 \\
\hline $\begin{array}{l}\text { Decapoda } \\
\quad \text { Sergestes similis }\end{array}$ & 1.7 & 21.4 & 9.7 & 1.5 \\
\hline Crustacea (unidentified) & 0.6 & 0.4 & 3.9 & \\
\hline Ophiuroidea (unidentified) & 0.1 & 0.2 & 1.0 & $<0.1$ \\
\hline $\begin{array}{l}\text { No. identifiable prey item } \\
\text { No. unidifiable material } \\
\text { No. stomachs containing identifiable prey items } \\
\text { No. stomachs examined } \\
\text { No. empty stomachs }\end{array}$ & & $\begin{array}{r}693 \\
1 \\
103 \\
106 \\
2\end{array}$ & & \\
\hline
\end{tabular}

$C n$, percentage of identifiable prey of the total number; $W W$, percentage of identifiable prey of the total wet weight; $F$, percentage frequency of occurrence of identifiable prey; \%IRI, index of percentage relative importance.

5.702, $P<0.001, t$-test; Fig. 2). In contrast, the number of euphausiids ingested per stomach was significantly higher in October than in April ( $U=$ 291, $P<0.001$, Mann-Whitney $U$-test). There was no significant difference in SCI between April and October $(U=779, \quad P=0.083$, Mann-Whitney $U$ test). Furthermore, the SL of fish that preyed on $E$. pacifica did not differ by month (125.0 \pm 7.3 and $127.3 \pm 6.7 \mathrm{~mm}$ in April and October, respectively; $U=612, P=0.146$, Mann-Whitney $U$-test).

\section{DISCUSSION}

In the depth range (343-1408 $\mathrm{m}$ ) sampled in the present study, $93 \%$ of $N$. japonicus were collected at 373-417 $\mathrm{m}$ depth. This range corresponded with the known depth range of vertical distribution of $N$. japonicus, which is $300-500 \mathrm{~m}$ in both offshore ${ }^{11}$ and near-shore (K Uchikawa, unpubl. data, 1998) waters during the daytime. The occurrence of $N$. japonicus near the sea floor on the upper conti- 


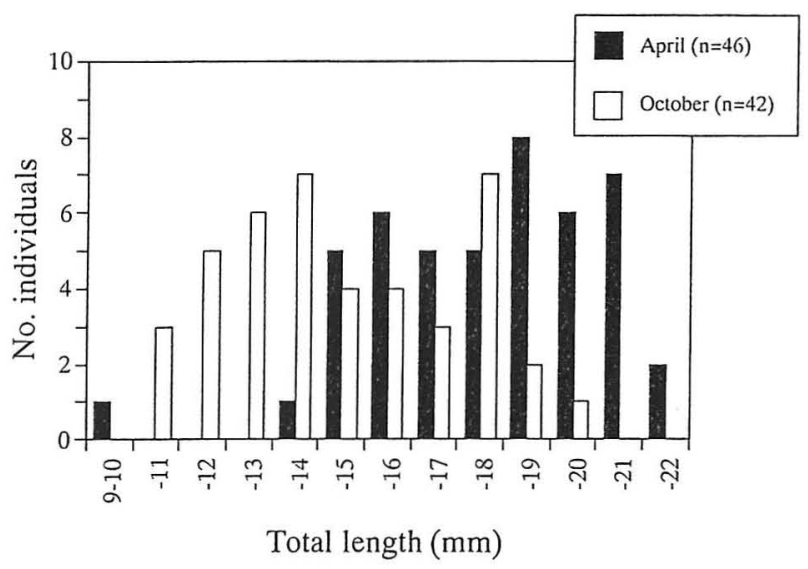

Fig. 2 Size distribution of Euphausia pacifica ingested by Notoscopelus japonicus.

nental slope is presumably a result of the interruption of its downward migration by the sea floor. ${ }^{25-27}$ Thus, at bottom depths less than $500 \mathrm{~m}$, this species will be associated with the bottom during the daytime. The few specimens collected in bottom tows at depths $>500 \mathrm{~m}$ may have been collected during the net's ascent and descent through the 300-500 $\mathrm{m}$ range.

Like other myctophids, ${ }^{25,28-31} N$. japonicus feed mainly on crustaceans. No seasonal dietary shift was observed. This reflects a high dependence on $E$. pacifica in both April and October. Euphausia pacifica is one of the most abundant zooplankton in the Tohoku region ${ }^{32-34}$ and undertakes diel vertical migration (DVM) between 200 and $400 \mathrm{~m}$ depths during the daytime and the surface layer at night. ${ }^{34-}$ ${ }^{36}$ Because $N$. japonicus also undertakes DVM, ${ }^{11}$ it probably occurs at the same depths with E. pacifica during both the day and night. In the study area, dense aggregations of $E$. pacifica have been observed not only in the surface layer at night, ${ }^{32,37}$ but also in the near-bottom layer during the daytime. ${ }^{38,39}$ Aggregations of euphausiids in the near-bottom layers are thought to result from the interruption of their downward migration by the shallow sea floor and will increase their exposure to near-bottom predators..$^{20,40,41}$ At depths less than approximately $400 \mathrm{~m}$, E. pacifica were presumably trapped near the sea floor during the daytime, which plausibly improved the feeding conditions for $N$. japonicus. Thus, $N$. japonicus would have had access to aggregations of E. pacifica both in the surface layer at night and in the near-bottom layer during the daytime. Migrant myctophids feed mainly in the surface layers at night, ${ }^{42-44}$ but there are some reports of daytime feeding by migrant myctophids in productive areas, such as subarc- tic/transitional, ${ }^{31}$ upwelling ${ }^{45,46}$ and upper-slope areas. ${ }^{28,29,47-49}$ Although we have no data on feeding periodicity, it seems likely that active feeding during the daytime by $N$. japonicus enhanced the importance of E. pacifica as food.

The average size of prey ingested by $N$. japonicus was 15.5 and $13.8 \mathrm{~mm}$ in April and October, respectively. This result indicated that $N$. japonicus ingested larger prey compared with other myctophids; Diaphus taaningi (most prey were $<4 \mathrm{~mm}$ ), ${ }^{50}$ Lampanyctus alatus (most prey were $<4 \mathrm{~mm})^{51}$ and Benthosema glaciale (prey were $\leq 7 \mathrm{~mm}) .^{52}$ Two factors are probably responsible for the differences. The positive relationship between predator and prey sizes has been widely reported for fish with particulate feeding. ${ }^{53}$ Notoscopelus japonicus examined in the present study had a larger body size compared with the other myctophid fishes cited above and this would have resulted in a larger prey size. Another possibility is size composition of prey available. The predominant prey for $N$. japonicus was $E$. pacifica, which has a far larger body size compared with other common prey for myctophids, such as copepods and ostracods. As discussed below, an enhanced availability of E. pacifica in the bottom layer would have resulted in the large prey size of $N$. japonicus. The size of E. pacifica ingested by $N$. japonicus was significantly larger in April than in October, whereas the number of euphausiids per fish stomach significantly increased from April to October. Because the median size of $N$. japonicus examined in the present study did not differ seasonally, the decrease in prey size rather reflects the change in the size composition of available prey. In the Tohoku region, E. pacifica grows rapidly from 13 to $18 \mathrm{~mm}$ TL during March to May and growth is suspended through the winter. ${ }^{54}$ Euphausia pacifica matures when it grows to $13 \mathrm{~mm} \mathrm{TL} \mathrm{TL}^{55}$ and spawns mainly during spring to early summer. ${ }^{54,56}$ In our results, $>98 \%$ of $E$. pacifica were $>13 \mathrm{~mm}$ TL in April, whereas $67 \%$ of E. pacifica ingested were $>$ $13 \mathrm{~mm}$ TL in October. These results suggest that the difference in size composition resulted from seasonal dynamics of the E. pacifica population. Because there was no significant seasonal difference in feeding intensity $(S C D$ ), in October $N$. japonicus appears to feed on larger numbers of smaller E. pacifica rather than shifting to other prey taxa.

Euphausia pacifica is an important prey for vertically migrating myctophids, such as Diaphus theta and Stenobrachius leucopsarus, in the northwestern North Pacific. ${ }^{31}$ However, unlike N. japonicus in the present study, these two myctophids feed heavily on taxa other than euphausiids. Cope- 
pods are generally the major prey of midwater fishes in oceanic regions, whereas euphausiids become more important in areas closer to land. ${ }^{29}$ Aggregations of euphausiids in the continental slope regions ${ }^{38-40,57,58}$ would enhance the availability and importance of euphausiids as prey. Gartner et $a .^{25}$ suggested that myctophids may approach the bottom not only because of the interruption of downward migration, but also due to the high prey concentrations in the benthopelagic layer over the continental slopes. Therefore, the pronounced importance of E. pacifica in the diet of $N$. japonicus is ascribed to the dense aggregation of E. pacifica being accessible during both day and night.

\section{ACKNOWLEDGMENTS}

We thank T Hattori, H Imamura, G Shinohara and the officers and crew of the R/Vs Tansyu-Maru and Wakataka-Maru for their help with sampling at sea. We also thank JR Bower (Hokkaido University) for his helpful comments on the manuscript and $\mathrm{N}$ Shiga and Y Yamada (Hokkaido University) and T Komai (Natural History Museum and Institute) for prey identification. We are also grateful to $\mathrm{H}$ Ogi (Hokkaido University), H Ohizumi (National Research Institute of Far Seas Fisheries) and P Dalpadado (Institute of Marine Research) for their helpful discussions.

\section{REFERENCES}

1. Beamish RJ, Leask KD, Ivanov OA, Balanov AA, Orlov AA, Sinclair B. The ecology, distribution, and abundance of midwater fishes of the Subarctic Pacific gyres. Prog. Oceanogr. 1999; 43: 399-442.

2. Schneider D, Hunt Jr GL. A comparison of seabird diets and foraging distribution around the Pribilof Islands, Alaska. In: Nettleship DN, Sanger GA, Springer PF (eds). Marine Birds: Their Feeding Ecology and Commercial Fisheries Relationships. Minister of Supply and Services Canada, Ottawa. 1984; 86-95.

3. Ohizumi H, Yoshioka M, Mori K, Miyazaki N. Stomach contents of common dolphins (Delphinus delphis) in the pelagic western North Pacific. Mar: Mamm. Sci. 1998; 14: 835-844.

4. Pearcy WG, Brodeur RD, Shenker JM, Smoker WW, Endo Y. Food habits of Pacific salmon and steelhead trout, midwater trawl catches and oceanographic conditions in the Gulf of Alaska, 1980-85. Bull. Ocean. Res. Inst. Univ. Tokyo 1988; 26: 29-78.

5. Nafpaktitis BG, Backus RH, Craddock JE, Haedrich RL, Robinson BH, Karnella C. Family Myctophidae. In: Gibbs Jr RH (ed.). Fishes of the Western North Atlantic, Part 7. Sears Foundation for Marine Research, New Haven. 1977; 13-265.

6. Crawford RJM. Occurrence and distribution of lantern- fish Lampanyctodes hectoris catches in the South African purse-seine fishery, 1968-76. Fish. Bull. S. Afr. 1980; 13: 111-136.

7. Hulley PA, Lutjeharms JRE. Lanternfishes of the southern Benguela region. Part 3 . The pseudoceanic-oceanic interface. Ann. S. Afr. Mus. 1989; 98: 409-435.

8. Williams A, Koslow JA. Species composition, biomass and vertical distribution of micronekton over the mid-slope region off southern Tasmania, Australia. Mar: Biol. 1997; 130: 259-276.

9. Fujii E, Uyeno T. On three species of the myctophid genus Notoscopelus found in western North Pacific. Jpn. J. Ichthyol. 1976; 22: 227-233 (in Japanese).

10. Willis JM, Pearcy WG, Parin NV. Zoogeography of midwater fishes in the Subarctic Pacific. Bull. Ocean Res. Inst. Univ. Tokyo 1988; 26: 79-142.

11. Watanabe H, Moku M, Kawaguchi K, Ishimaru K, Ohno A. Diel vertical migration of myctophid fishes (Family Myctophidae) in the transitional waters of the western North Pacific. Fish. Oceanogr: 1999; 8: 115-127.

12. Mead GW, Taylor FHC. A collection of oceanic fishes from off northeastern Japan. J. Fish. Res. Bd Can. 1953; 10: 560-582.

13. Wada K. Food and feeding habit of Northern Fur Seals along the coast of Sanriku. Bull. Tokai Reg. Fish. Res. Lab. 1971; 64: 1-37 (in Japanese).

14. Wilke F, Nicholson AJ. Food of porpoises in waters off Japan. J. Mamm. 1958; 39: 441-443.

15. Ohizumi H. Feeding ecology of Dall's porpoise (Phocoenoides dalli). $\mathrm{PhD}$ Thesis, University of Tokyo, Tokyo, 1998 (in Japanese).

16. Yamamura O, Inada T. Importance of micronekton as food of demersal fish assemblages. Bull. Mar: Sci. 2001; 68: 13-25.

17. Pinkas L, Oliphant MS, Iverson ILK. Food habits of albacore, bluefin tuna, and bonito in California waters. Calif. Dept Fish Game Fish. Bull. 1971; 152: 1-105.

18. Cortés E. A critical review of methods of studying fish feeding based on analysis of stomach contents: Application to elasmobranch fishes. Can. J. Fish. Aquat. Sci. 1997; 54: 726-738.

19. Schoener TW. The Anolis lizards of Bimini: Resource partitioning in a complex fauna. Ecology 1968; 49: 704-726.

20. Brodeur RD, Pearcy WG. Food habits and dietary overlap of some shelf rockfishes (genus Sebastes) from the northeastern Pacific Ocean. Fish. Bull. 1984; 82: 269-293.

21. Langton RW. Diet overlap between Atlantic cod, Gadus morhua, silver hake, Merluccius bilinearis, and fifteen other northwest Atlantic finfish. Fish. Bull. 1982; 80: 745-759.

22. Ross ST. Resource partitioning in fish assemblages: A review of field studies. Copeia 1986; 1986: 352-388.

23. Kawai H. Hydrography of the Kuroshio Extension. In: Stommel H, Yoshida K (eds). Kuroshio: Its Physical Aspects. University of Tokyo Press, Tokyo. 1972; 235-352.

24. Mizuno K. Notes on the hydrographic variability in the vicinity of the east coast of Japan. Bull. Tohoku Reg. Fish. Res. Lab. 1984; 46: 61-80 (in Japanese).

25. Gartner Jr JV, Crabtree RE, Sulak KJ. Feeding at depth. In: Randall DJ, Farrell AP (eds). Deep-Sea Fish. Academic Press, London. 1997; 115-193.

26. Marshall NB, Merrett NR. The existence of a benthopelagic fauna in the deep-sea. A voyage of discovery. Deep Sea Res. 1977; Suppl.: 483-497. 
27. Mauchline J, Gordon JDM. Oceanic pelagic prey of benthopelagic fish in the benthic boundary layer of a marginal oceanic region. Mar: Ecol. Prog. Ser: 1991; 74: 109-115.

28. Tyler Jr HR, Pearcy WG. The feeding habits of three species of lanternfishes (family Myctophidae) off Oregon, USA. Mar: Biol. 1975; 32: 7-11.

29. Young JW, Blaber SJM. Feeding ecology of three species of midwater fishes associated with the continental slope of eastern Tasmania, Australia. Mar: Biol. 1986; 93: 147-156.

30. Kawamura K, Fujii F. Forage of the mesopelagic fishes, Symbolophorus californiensis (Eigenmann and Eigenmann) and Tarletonbeania taylori Mead caught in gill nets in the northwestern North Pacific Ocean. Bull. Ocean Res. Inst. Univ. Tokyo 1988; 26: 143-159.

31. Moku M, Kawaguchi K, Watanabe H, Ohno A. Feeding habits of three dominant myctophid fishes, Diaphus theta, Stenobrachius leucopsarus and S. nannochir; in the subarctic and transitional waters of the western North Pacific. Mar: Ecol. Prog. Ser. 2000; 207: 129-140.

32. Odate K. An euphausiid crustacea exploited along the Sanriku and Joban coast. Bulll. Tohoku Reg. Fish. Res. Lab. 1979; 40: 15-25 (in Japanese).

33. Odate $\mathrm{K}$. Zooplankton biomass and its long-term variation in the western North Pacific Ocean, Tohoku sea area, Japan. Bull. Tohoku Reg. Fish. Res. Lab. 1994; 56: 115-173 (in Japanese).

34. Taki K. Horizontal distribution and diel vertical migration of Euphausia pacifica Hansen in summer in and around a warm-core ring off Sanriku, northwestern Pacific. Bull. Tohoku Natl Fish. Res. Inst. 1998; 60: 49-61.

35. Brinton E. The distribution of Pacific euphausiids. Bull. Scripps Ocean. Univ. Calif. 1962; 8: 51-270.

36. Youngbluth MJ. Vertical distribution and diel migration of euphausiids in the central region of the California current. Fish. Bull. 1976; 74: 925-936.

37. Terazaki M. Surface swarms of a euphausiid Euphausia pacifica in Otsuchi Bay, northern Japan. Bull. Plankton Soc. Jpn 1980; 27: 19-25.

38. Izumi Y, Kodama J. Observation bottom swarm of the krill, Euphausia pacifica from a submersible, 'Sinkai' 2000. In: Report of the Research Meeting on North Pacific Krill Resources, Report no. 4. Tohoku National Research Institute, Shiogama. 1995; 104-105 (in Japanese).

39. Taki K, Kotani Y, Endo Y. Ecological studies on Euphausia pacifica Hansen and seasonal changes of its environment off Onagawa, Miyagi prefecture III. Distribution and diel vertical migration of Euphausia pacifica. Bull. Tohoku Natl Fish. Res. Inst. 1996; 58: 89-104.

40. Simard Y, Mackas DL. Mesoscale aggregations of euphausiid sound scattering layers on the continental shelf of Vancouver Island. Can. J. Fish. Aquat. Sci. 1989; 46: 1238-1249.

41. Yamamura O, Inada T, Shimazaki K. Predation on Euphausia pacifica by demersal fishes: Predation impact and influence of physical variability. Mar: Biol. 1998; 132: 195-208.

42. Kinzer J, Schulz K. Vertical distribution and feeding patterns of midwater fish in the central equatorial Atlantic. I. Myctophidae. Mar: Biol. 1985; 85: 313-322.

43. Clarke TA. Diel feeding patterns of 16 species of mesopelagic fishes from Hawaiian waters. Fish. Bull. 1978; 76: 495-513.

44. Hopkins TL, Baird RC. Aspects of the feeding ecology of oceanic midwater fishes. In: Anderson NR, Zahuranec BJ (eds). Oceanic Sound Scattering Prediction. Plenum Press, New York. 1977; 325-360.

45. Kinzer J. The food of four myctophid fish species off Northwest Africa. Rapp. P.-V. Réun. Cons. Int. Explor: Mer: 1982; 180: 385-390.

46. Kinzer J. Observations on feeding habits of the mesopelagic fish Benthosema glaciale (Myctophidae) off NW Africa. In: Anderson NR, Zahuranec BJ (eds). Oceanic Sound Scattering Prediction. Plenum Press, New York. 1977; 381-392.

47. Paxton JR. Biological notes on southern California lanternfishes (family Myctophidae). Calif. Fish Game. 1967; 53: 214-217.

48. Samyshev EZ, Schteinkin SV. Feeding patterns of some species of myctophids and Maurolicus muelleri caught in the sound-dispersing layers in the northwestern African area. Ann. Biol. 1971; 28: 212-215.

49. Gjøsæter J. Life history and ecology of the myctophid fish Notoscopelus elongatus kroeyeri from the northeast Atlantic. Fiskdir: Skr. Ser: Havunders. 1981; 17: 133-152.

50. Baird RC, Hopkins TL, Wilson DF. Diet and feeding chronology of Diaphus taaningi (Myctophidae) in the Cariaco Trench. Copeia 1975; 1975: 356-365.

51. Hopkins TL, Baird RC. Aspects of the trophic ecology of the mesopelagic fish Lampanyctus alatus (Family Myctophidae) in the eastern Gulf of Mexico. Biol. Oceanogr. 1985; 3: 285-313.

52. Sameoto DD. Feeding of lantern fish Benthosema glaciale off the Nova Scotia Shelf. Mar. Ecol. Prog. Ser: 1988; 44: 113-129.

53. Gerking SD. Feeding Ecology of Fish. Academic Press, San Diego. 1994.

54. Taki K, Ogishima T. Distribution of some developmental stages and growth of Euphausia pacifica Hansen in the northwestern Pacific on the basis of Norpac net samples. Bull. Tohoku Natl Fish. Res. Inst. 1997; 59: 95-117 (in Japanese).

55. Endo Y. Daytime surface swarming of Euphausia pacifica (Crustacea: Euphausiacea) in the Sanriku coastal waters off northeastern Japan. Mar: Biol. 1984; 79: 269-276.

56. Terazaki M, Kitagawa D, Yamashita Y. Occurrence of Euphausia pacifica Hansen (Crustacea: Euphausiacea) with spermatophore in the vicinity of Otsuchi, northeastern Japan. Bull. Jpn. Soc. Sci. Fish. 1986; 52: 1355-1358.

57. Pearcy WG. Seasonal and inshore-offshore variations in the standing stocks of micronekton and macrozooplankton off Oregon. Fish. Bull. 1976; 74: 70-80.

58. Fulton J, LeBrasseur R. Euphausiids of the continental shelf and slope of the Pacific coast of Canada. La Mer: 1984; 22: 268-276. 